\title{
Effect of Mycorrhizal Fungi and Potting Media on Nutrient Content in Soil and Uptake by Ailanthus excelsa Seedlings
}

\author{
Ishwar Anand ${ }^{1}$, M. K. Singh ${ }^{1}$, R. S. Beniwal ${ }^{1}$, K. K. Bhardwaj ${ }^{2}$, \\ R. K. Chugh ${ }^{3 *}$ and Sanjay Kumar ${ }^{4}$ \\ ${ }^{1}$ Department of Forestry, ${ }^{2}$ Department of Soil Science \\ ${ }^{3}$ Department of Plant Pathology, ${ }^{4}$ Department of Agriculture Economics \\ Chaudhary Charan Singh Haryana Agircultural University, Hisar, India \\ *Corresponding author
}

\begin{abstract}
A B S T R A C T
Keywords

Acaulospora

scrobiculata,

Glomus

intraradices,

Ailanthus excelsa,

Potting media

Article Info

Accepted:

18 May 2020

Available Online:

10 June 2020

An experiment was conducted in nursery condition of Department of Forestry, CCSHAU, Hisar. Pots were filled with different soils media containing field soil (FS), farm yard manure (FYM) and pond silt (PS) inoculated with two mycorrhizal fungi i.e. Glomus intraradices (G.I) and Acaulospora scrobiculata (A.S). Seeds of Ailanthus excelsa were sown in pots for studied the nutrient contents in soil $(\mathrm{kg} / \mathrm{ha})$, nutrient content in plants $(\%)$ and uptake by plants (g/plant). It was observed that nutrient contents in soils and uptake in plants were increased with increasing time period when both the mycorrhizal fungi were applied separately in potting media containing field soil and farm yard manure but show negative effect on nutrient contents in soil and uptake in plants when both these fungi were applied together.
\end{abstract}

\section{Introduction}

Ailanthus excelsa (Roxb) commonly called Ardu belongs to the family Simaroubaceae. It is a deciduous multipurpose tree grows well in arid and semi-arid regions, its grows well in all types of soil but performed better in porous sandy-loams soil. Its leaves can feed to ruminant animals in the month of April to June and November to January in drought condition. It is one of the most important tree species in arid ecosystem to sustain the productivity of animals like goat and sheep (Jat et al., 2011).

It is cultivated for anti-erosion purposes in arid and semi-arid regions of the country. It is usually absent in heavy clay soils, water logged area and high rainfall area with poor drainage. 
For the successful plantation of Ardu in arid and semi-arid region, it is necessary that its roots can be inoculated with mycorrhizal fungi before planting out from nursery because these fungi play an important role in increases the absorption area of trees roots and solubilize the essential plant nutrients. Arbuscular mycorrhizal fungi (AMF) are obligate biotrophs, which can form mutualistic symbioses with the roots of plant species (Giovannetti, 2008). AMF symbiosis can develop extra-radical mycelia, which disperse outside the roots to have access to a greater quantity of water and soil minerals for the host plants. In return, these mycorrhizal fungi receive plant carbohydrates for the completion of its life cycle (Genre and Bonfante, 2010). Mycorrhizal fungi are associated with the roots of plants to enhance the growth and nutrients uptake resulting in increased growth of plants (Miransari, 2010), these fungi also helps in improving tolerance to stress conditions (Dell'Amico et. al. 2002). It's also help to enhance the growth of seedlings and survivals of plants under nursery conditions (Guissou et. al. 2016).

Keeping in view the above facts the experiment was conducted to study the effect of mycorrhizal fungi on nutrients content in soil, plants and uptake by the seedlings of Ailanthus excelsa grown in different potting media under nursery condition.

\section{Materials and Methods}

\section{Climate and weather}

The climate of Hisar (Haryana) is semi-arid with hot and dry desiccating winds accompanied by frequent dust storms with high velocity in summer months, severe cold during in winter months and humid warm during monsoon rainy season. The mean monthly maximum and minimum temperature sometimes exceeds $48^{0} \mathrm{C}$ in hot summer days. Relative humidity varies from 5 to 100 percent, while temperature below freezing point accompanied by frost in winter is usually experienced in this region.

\section{Preparation of soil and nutrients analysis}

Field soil (FS) were collected from Balsamand Research Farm, CCSHAU, Hisar and mixed with well rotted Farm Yard Manure (FYM) and pond silt (PS) in 1:1:1 ratio. These potting mixtures were autoclaved at $120^{\circ} \mathrm{C}$ for 30 minutes for disinfectant. Seeds of Ailanthus excelsa collected from plus tree at Balsamand Research Farm were sown about 2-3 cm deep in polybags of $1 \mathrm{~kg}$ capacity with mixing of $10 \mathrm{~g} / \mathrm{kg}$ inoculums of AM fungi i.e., Acaulospora scrobiculata (A.S) and Glomus intraradices (G.I)) include rhizospheric soil and roots to studied the N, P and $\mathrm{K}$ contents. Available soil nutrients were analyzed by following the procedure given by Subbiah and Asija (1956), Olsen (1952) and Hanway and Heidel (1952) respectively before the seed sowing and after the harvest of the seedlings. total nitrogen content was estimated by using Nessler's reagent, total phosphorous was determined by vanadomolybdate yellow color method by using spectrophotometer and total potassium was determined by using flame photometer in plants and uptake of nutrients was calculated by using the formula $\mathrm{N}, \mathrm{P}$ and $\mathrm{K}$ plants (\%) $\mathrm{x}$ total dry weight of corresponding plants $(\mathrm{g})$. The various combination of potting mixture filled in polybags were Contol (only FS), FS + G.I, FS + A.S, FS + FYM (1:1), FS + PS (1:1), FS + FYM + G.I (1:1), FS + FYM + A.S (1:1), FS + PS + G.I (1:1), FS + PS + A.S $(1: 1), F S+P S+F Y M+$ G.I $(1: 1: 1), F S+P S$ + FYM + A.S (1:1:1), FS + PS + FYM + A.S + G.I $(1: 1: 1)$.

\section{Statistics analysis}

Seedlings of Ailanthus excelsa were maintained in nursery condition in CRD with 
twelve treatments inoculated with two AM fungi. Ten replications with three plants per replications were used for each treatment. Statistical procedures were carried out with the Software Package OPSTAT developed by CCSHAU, Hisar with significant differences were based on $5 \%$.

\section{Results and Discussion}

Result of available N, P and K (kg/ha) contents in soils of different potting mixtures were analyzed at the time of sowing and after harvest are presented in Table-1. In treatment i.e., Field soil + FYM + Glomus intraradices, $\mathrm{N}, \mathrm{P}$ and $\mathrm{K}$ contents were found 124.40 , $14.50,270.50 \mathrm{~kg} / \mathrm{ha}$ respectively at time of sowing which was statistically at par with Field soil + FYM (1:1) 124.00, 14.50, 269.70 $\mathrm{kg} / \mathrm{ha}$ followed by Field soil + FYM + Acaulospora scrobiculata (1:1) 123.80, 14.40, $269.30 \mathrm{~kg} / \mathrm{ha}$ as compared with control at time of sowing.

However, similar pattern of nutrients contents were recorded after harvest of Ailanthus excelsa seedlings. Basumatary et al., (2014) reported that available nutrient contents like nitrogen, phosphorous, potassium and carbon in soil was found significantly higher when soil infested with Acaulospora sp. and Glomous sp. over control. Han et al., (2016) concluded that organic manure originating from livestock byproducts and sawdust not only promoted the growth of yellow poplar but also improved soil conditions.

It is clearly evident from the data presented in Table-2 that significantly higher nitrogen (1.78 and $1.86 \%)$, phosphorus (0.19 and $0.22 \%)$ and potassium (0.83 and $0.88 \%)$ content in plant after three and six months old seedlings in treatment Field soil + FYM + Glomus intraradices $(1: 1)$ followed by treatment Field soil + FYM + Acaulospora scrobiculata (1:1) over control. Moreover, N,
$\mathrm{P}$ and $\mathrm{K}$ content $(\%)$ in plants was recorded higher in potting media mixed of field soil with FYM followed by field soil with FYM and pond silt and minimum in control as field soil. Nutrient contents i.e., N, P and K in soil was found significantly higher in potting media containing AM fungi with FYM than other potting media.

Dhar and Mridha (2012) suggested that mycorrhiza help in nutrient cycling for the establishment of plants. Mycorrhiza helps in increase in the availability of nutrient content to the plants mainly $\mathrm{N}, \mathrm{K}$ and Ca reported by Filho et al., (2017) in star fruits. Anand et. al., (2020) also reported that the seedlings of Ailanthus excelsa performed significantly better in the soils containing individual mycorrhizal fungi either Acaulospora scrobiculata or Glomus intraradices grow in potting media containing Field Soil + FYM.

The data presented in Table- 3 shows that the uptake of plant nutrients i.e. N, P and $\mathrm{K}$ was significantly higher in Field soil + FYM + Glomus intraradices (1:1) (2.37 g/plant) followed by Field soil + FYM + Acaulospora scrobiculata (2.31 g/plant), phosphorus in Field soil + FYM + Glomus intraradices (1:1) $(0.25 \mathrm{~g} /$ plant $)$ which was statistically at par with Field soil + FYM + Acaulospora scrobiculata (1:1) (0.25 g/plant) and potassium content in Field soil + FYM + Acaulospora scrobiculata (1:1) (1.13 g/plant) followed by Field soil + FYM + Glomus intraradices (1:1) (1.10 g/plant) and over control.

After six months of sowing in Field soil + FYM + Glomus intraradices (1:1) (12.50 g/plant, $1.48 \mathrm{~g} /$ plant, $5.91 \mathrm{~g} /$ plant) recorded significantly higher nitrogen, phosphorus and potassium content followed by Field soil + $\mathrm{FYM}+$ Acaulospora scrobiculata (1:1) (10.63 g/plant, $1.27 \mathrm{~g} /$ plant, $5.13 \mathrm{~g} /$ plant) and over control. 
Table.1 Available nitrogen, phosphorus and potassium content (kg/ha) before sowing and after harvest of seedlings

\begin{tabular}{|l|c|c|c|c|c|c|}
\hline \multicolumn{1}{|c|}{ Treatments } & \multicolumn{3}{c|}{ Before sowing } & \multicolumn{3}{c|}{ After sowing } \\
\cline { 2 - 7 } & N & P & K & N & P & K \\
\hline Contol (only FS), & 117.40 & 12.30 & 258.60 & 116.80 & 11.80 & 257.20 \\
\hline FS + G.I & 118.60 & 12.60 & 260.40 & 119.30 & 13.50 & 262.80 \\
\hline FS + A.S & 118.20 & 12.20 & 258.70 & 119.50 & 12.90 & 259.30 \\
\hline FS + FYM (1:1) & 124.00 & 14.50 & 269.70 & 123.30 & 14.00 & 266.10 \\
\hline FS + PS (1:1) & 121.50 & 13.40 & 262.10 & 120.60 & 12.80 & 261.30 \\
\hline FS + FYM + G.I (1:1) & 124.40 & 14.50 & 270.50 & 126.80 & 15.60 & 271.80 \\
\hline FS + FYM + A.S (1:1) & 123.80 & 14.40 & 269.30 & 125.60 & 14.70 & 270.60 \\
\hline FS + PS + G.I (1:1) & 121.80 & 13.50 & 261.80 & 123.70 & 14.60 & 263.40 \\
\hline FS + PS + A.S (1:1) & 122.30 & 12.90 & 262.40 & 124.40 & 13.70 & 263.00 \\
\hline FS + PS + FYM + G.I (1:1:1) & 123.70 & 14.20 & 267.40 & 126.40 & 15.30 & 269.20 \\
\hline FS + PS + FYM + A.S (1:1:1) & 123.40 & 14.10 & 268.60 & 125.80 & 14.70 & 269.50 \\
\hline FS + PS + FYM + A.S + G.I (1:1:1) & 117.90 & 12.80 & 261.60 & 118.70 & 13.10 & 262.20 \\
\hline CD at 5\% & $\mathbf{1 . 0 1}$ & $\mathbf{0 . 4 6}$ & $\mathbf{6 . 3 3}$ & $\mathbf{1 . 8 8}$ & $\mathbf{0 . 6 7}$ & $\mathbf{7 . 6 4}$ \\
\hline
\end{tabular}

FS: field soil, FYM: farm yard manure, PS: pond silt, G.I: Glomus intraradices, AS: Acaulospora scrobiculata

Table.2 Total nitrogen, phosphorus and potassium content (\%) in plant after three and six months of sowing

\begin{tabular}{|l|c|c|c|c|c|c|}
\hline \multicolumn{1}{|c|}{ Treatments } & \multicolumn{2}{|c|}{ After three months } & \multicolumn{3}{c|}{ After six months } \\
\cline { 2 - 6 } & N & P & K & N & P & K \\
\hline Contol (only FS), & 1.28 & 0.12 & 0.59 & 1.36 & 0.14 & 0.63 \\
\hline FS + G.I & 1.44 & 0.15 & 0.70 & 1.54 & 0.17 & 0.75 \\
\hline FS + A.S & 1.38 & 0.14 & 0.67 & 1.50 & 0.16 & 0.71 \\
\hline FS + FYM (1:1) & 1.35 & 0.13 & 0.66 & 1.42 & 0.15 & 0.70 \\
\hline FS + PS (1:1) & 1.30 & 0.12 & 0.64 & 1.39 & 0.14 & 0.68 \\
\hline FS + FYM + G.I (1:1) & 1.78 & 0.19 & 0.83 & 1.86 & 0.22 & 0.88 \\
\hline FS + FYM + A.S (1:1) & 1.65 & 0.18 & 0.81 & 1.76 & 0.21 & 0.85 \\
\hline FS + PS + G.I (1:1) & 1.57 & 0.17 & 0.73 & 1.64 & 0.20 & 0.78 \\
\hline FS + PS + A.S (1:1) & 1.51 & 0.16 & 0.71 & 1.62 & 0.18 & 0.74 \\
\hline FS + PS + FYM + G.I (1:1:1) & 1.64 & 0.16 & 0.77 & 1.73 & 0.19 & 0.82 \\
\hline FS + PS + FYM + A.S (1:1:1) & 1.62 & 0.15 & 0.77 & 1.71 & 0.17 & 0.80 \\
\hline FS + PS + FYM + A.S + G.I (1:1:1) & 1.32 & 0.14 & 0.64 & 1.41 & 0.17 & 0.67 \\
\hline CD at 5\% & $\mathbf{0 . 0 6}$ & $\mathbf{0 . 0 2}$ & $\mathbf{0 . 0 5}$ & $\mathbf{0 . 1 1}$ & $\mathbf{0 . 1 4}$ & $\mathbf{0 . 0 9}$ \\
\hline
\end{tabular}

FS: field soil, FYM: farm yard manure, PS: pond silt, G.I: Glomus intraradices, AS: Acaulospora scrobiculata 
Table.3 Nutrient uptake (g/plant) after three and six months of sowing

\begin{tabular}{|l|c|c|c|c|c|c|}
\hline \multirow{2}{*}{ Treatments } & \multicolumn{3}{|c|}{ After three months } & \multicolumn{3}{c|}{ After six months } \\
\cline { 2 - 7 } & $\mathbf{N}$ & $\mathbf{P}$ & $\mathbf{K}$ & $\mathbf{N}$ & $\mathbf{P}$ & K \\
\hline Contol (only FS), & 0.37 & 0.03 & 0.17 & 1.06 & 0.11 & 0.49 \\
\hline FS + G.I & 1.12 & 0.12 & 0.55 & 1.74 & 0.19 & 0.85 \\
\hline FS + A.S & 1.09 & 0.11 & 0.53 & 2.78 & 0.30 & 1.31 \\
\hline FS + FYM (1:1) & 0.57 & 0.05 & 0.28 & 3.12 & 0.33 & 1.54 \\
\hline FS + PS (1:1) & 0.46 & 0.04 & 0.22 & 3.35 & 0.34 & 1.64 \\
\hline FS + FYM + G.I (1:1) & 2.37 & 0.25 & 1.10 & 12.50 & 1.48 & 5.91 \\
\hline FS + FYM + A.S (1:1) & 2.31 & 0.25 & 1.13 & 10.63 & 1.27 & 5.13 \\
\hline FS + PS + G.I (1:1) & 1.57 & 0.17 & 0.73 & 5.36 & 0.65 & 2.55 \\
\hline FS + PS + A.S (1:1) & 1.42 & 0.15 & 0.67 & 4.96 & 0.55 & 2.26 \\
\hline FS + PS + FYM + G.I (1:1:1) & 1.75 & 0.17 & 0.82 & 7.53 & 0.83 & 3.57 \\
\hline FS + PS + FYM + A.S (1:1:1) & 1.86 & 0.17 & 0.89 & 7.75 & 0.77 & 3.62 \\
\hline FS + PS + FYM + A.S + G.I (1:1:1) & 0.48 & 0.05 & 0.23 & 2.43 & 0.29 & 1.15 \\
\hline CD at 5\% & $\mathbf{0 . 0 6}$ & $\mathbf{0 . 0 1}$ & $\mathbf{0 . 0 5}$ & $\mathbf{0 . 1 2}$ & $\mathbf{0 . 0 7}$ & $\mathbf{0 . 1 6}$ \\
\hline
\end{tabular}

FS: field soil, FYM: farm yard manure, PS: pond silt, G.I: Glomus intraradices, AS: Acaulospora scrobiculata

Nutrient uptake in Ailanthus excelsa seedling was recorded three and six months after sowing in different potting mixture and nutrient uptake were significantly higher in the treatment containing Field soil + FYM+ Acaulospora scrobiculata followed by Field soil + FYM + Glomus intraradices over control and other treatments under study. Caglar and Akgun (2006) suggested that uptake of nitrogen in leaf of Pistacia seedlings was higher when inoculated with Glomous species.

Chen et al., (2017) reported the increase in uptake of $\mathrm{P}$ and $\mathrm{K}$ in plant parts inoculated with Glomous mosseae. Nutrient uptake of N, $\mathrm{P}, \mathrm{K}, \mathrm{Ca}, \mathrm{Mg}$ and $\mathrm{Zn}$ in E. oleracea seedlings were significantly increased with the application of mycorrhizae in the soil reported by Chu (1999). Nutrient uptake was increased in the different plant species with the application of different mycorrhizal species reported by Ortiz et al., (2017). Singh and Chugh (2019) reported that seedlings of Prosopis cineraria, Dalbergia sissoo, E. tereticornis and Ailanthus excelsa were shown in the soils containing mycorrhizal fungi has significantly higher $\mathrm{N}, \mathrm{P}$ and $\mathrm{K}$ contents as compared to the plants grown in the soil without inoculated with mycorrhizal fungi. Based on above mentioned results it may be concluded that potting media containing Field soil + FYM + Glomus intraradices followed by Field soil + FYM + Acaulospora scrobiculata had better performance in terms of soil nutrients and nutrients uptake in Ailanthus excelsa seedlings during three and six months of experimentation. Further, it was also observed that combinations of both the mycorrhizae namely Glomus intraradices and Acaulospora scrobiculata in potting media had significantly poor effect. Potting media containing Field soil + FYM performed better than containing Field soil + Pond silt with mycorrhiza inoculum also observed during experimentation. Finally, it was recorded that potting media containing Field soil + FYM with individual mycorrhiza performed better than potting media containing Field soil + FYM + Pond silt with both the mycorrhizae inoculums. 


\section{Acknowledgements}

The authors are thankful to Dr. K.S. Bangarwa (Professor), Department of forestry, CCSHAU, Hisar for providing valuable guidance and suggestions during experimentation.

\section{References}

Anand, I, Singh, M.K and Kumar, S (2020). Effect of Acaculospora scrobiculata and Glomus intraradices on the growth of Ailanthus excelsa seedlings. International Journal of Agriculture Sciences, 12(9): 9812-9815.

Basumatary, N., Parkash, V., Tamuli, A.K., Saikia, A.J. and Teron, R. (2014). Arbuscular mycorrhizal inoculation affects growth and rhizospheric nutrient availability in Hevea brasiliensis (Willd. ex A. Juss.) Mull. Arg. clones. International Journal of Current Biotechnology, 2(7): 14-21.

Caglar, S. and Akgun, A. (2006). Effects of vesicular- arbuscular mycorrhizal (VAM) fungi on the seedling growth of three Pistacia species. Journal of Environmental Biology, 27(3): 485489.

Chen, M., Yang, G., Sheng, Y., Li, P., Qiu, H., Zhou, X., Huang, L. and Chao, Z. (2017). Glomus mosseae inoculation improves the root system architecture, photosynthetic efficiency and flavonoids accumulation of liquorice under nutrient stress. Frontiers in Plant Science, 8(931): 1-10.

Chu, E.Y. (1999). The effects of arbuscular mycorrhizal fungi inoculation on Euterpe oleracea Mart.(AÇAÍ) seedlings. Pesquisa Agropecuária Brasileira, 34(6): 1018-1024.

Dell'Amico, J., Torrecillas, A., Rodriguez, P., Morte, A. and Sanchez-Blanco, M.J. (2002). Responses of tomato plants associated with the arbuscular mycorrhizal fungus Glomus clarum during drought and recovery. The Journal of Agricultural Science, 138(4): 387-393.

Dhar, P.P. and Mridha, M.A.U. (2012). Arbuscular mycorrhizal associations in different forest tree species of Hazarikhil forest of Chittagong, Bangladesh. Journal of Forestry Research, 23(1): 115-122.

Filho, J.A.V., Mendonça Freitas, M.S., Martins, M.A., dos Santos, P.C. and Cordeiro de Carvalho, A.J. (2017). Arbuscular mycorrhizal fungi and phosphate fertilization on star fruit tree seedlings. Revista Brasileira de Ciências Agrárias, 12(1): 14-19.

Genre, A. and Bonfante, P. (2010). The making of symbiotic cells in arbuscular mycorrhizal roots. In Arbuscular mycorrhizas: Physiology and function, pp. 57-71.

Giovannetti, M. (2008). Structure, extent and functional significance of belowground arbuscular mycorrhizal networks. In: Varma, A. (Ed.) Mycorrhiza: State of the Art, Genetics and Molecular Biology, Eco-Function, Biotechnology, Eco-Physiology, Structure and Systematics. Third edition. SpringerVerlag,Berlin Heidelberg, pp. 59-72.

Guissou, T., Babana, A.H., Sanon, K.B. and Ba, A.M. (2016). Effects of arbuscular mycorrhizae on growth and mineral nutrition of greenhouse propagated fruit trees from diverse geographic provenances. Biotechnol. Agron. Soc. Environ., 20(3): 417-426.

Han, S.H., An, J.Y., Hwang, J., Kim, S.B. and Park, B.B. (2016). The effect of organic manure and chemical fertilizer on the growth and nutrient concentration of yellow poplar (Liriodendron tulipifera Lin.) in nursery system. Journal of Forest Science and Technology, 
12(3):137-143.

Hanway, J.J. and Heidel, H. (1952). Soil analysis methods as used in Iowa state college soil testing laboratory. Iowa Agriculture, 57: 1-31.

Jat, H.S., Singh R.K. and Mann, J.S. (2011). Ardu (Ailanthus sp.) in arid ecosystem: A compatible species for combating with drought and securing livelihood security of resource poor people. Indian Journal of Traditional Knowledge, 10: 102-113.

Miransari, M. (2010). Contribution of arbuscular mycorrhizal symbiosis to plant growth under different types of soil stress. Plant Biology, 12(4): 563569.

Olsen, S.R. (1954). Estimation of available phosphorus in soils by extraction with sodium bicarbonate. United States Department Of Agriculture; Washington.

Ortiz, Y.R., Bello, C.H.Á., Alarcón, A. and Cerrato, R.F. (2017). Effectiveness of native arbuscular mycorrhiza on the growth of four tree forest species from the Santa Marta Mountain, Veracruz (Mexico). Forest Systems, 26(1): 3.

Singh, M.K and Chugh, R.K (2019). Impact of Arbuscular Mycorrhizal fungi on the growth parameters and nutrients content on different tree species. Indian Journal of Pure and Applied Biosciences, 7 (6): 244-248.

Subbiah, B.V. and Asija G.H.(1956). A rapid procedure for estimation of available nitrogen in soil. Curr. Sci., 25: 259260.

\section{How to cite this article:}

Ishwar Anand, M. K. Singh, R. S. Beniwal, K. K. Bhardwaj, R. K. Chugh and Sanjay Kumar. 2020. Effect of Mycorrhizal Fungi and Potting Media on Nutrient Content in Soil and Uptake by Ailanthus excelsa Seedlings. Int.J.Curr.Microbiol.App.Sci. 9(06): 912-918. doi: https://doi.org/10.20546/ijcmas.2020.906.114 